\title{
Nanoencapsulation for Agri-Food Applications and Associated Health and Environmental Concerns
}

\author{
Dipendra Kumar Mahato ${ }^{1 \dagger}$, Awdhesh Kumar Mishra ${ }^{2 \dagger}$ and Pradeep Kumar ${ }^{3 *}$ \\ ${ }^{1}$ Consumer-Analytical-Safety-Sensory Food Research Centre, School of Exercise and Nutrition Sciences, Deakin University, \\ Burwood, VIC, Australia, ${ }^{2}$ Department of Biotechnology, Yeungnam University, Gyeongsan, South Korea, ${ }^{3}$ Applied \\ Microbiology Laboratory, Department of Forestry, North Eastern Regional Institute of Science and Technology, Nirjuli, India
}

Keywords: nanoparticle, human health, food and agriculture, environment concern, toxicity

\section{INTRODUCTION}

Food safety and security are vital to guarantee a sustainable and reliable energy source for human. There is a recent trend of nano-encapsulating bioactive compounds from both plant and animal sources and their utilization for various food applications (1). Nanoencapsulation has gained special attention because of its unique feature for efficient encapsulation, enhanced stability, and better controlled release of encapsulated materials $(2,3)$. Nanoencapsulation is

OPEN ACCESS

Edited by:

Marco lammarino,

Istituto Zooprofilattico Sperimentale di Puglia e Basilicata (IZSPB), Italy

Reviewed by:

Ashish Rawson,

Indian Institute of Food Processing

Technology, India

Otniel Freitas-Silva,

Embrapa Food agroindustry, Brazil

*Correspondence:

Pradeep Kumar

pkbiotech@gmail.com

tThese authors have contributed equally to this work

Specialty section:

This article was submitted to

Food Chemistry,

a section of the journal

Frontiers in Nutrition

Received: 02 February 2021 Accepted: 12 March 2021

Published: 08 April 2021

Citation:

Mahato DK, Mishra AK and Kumar P (2021) Nanoencapsulation for

Agri-Food Applications and Associated Health and Environmental Concerns. Front. Nutr. 8:663229.

doi: 10.3389/fnut.2021.663229 also applied for food packaging system with the use of biodegradable polymers reinforced with nanofillers as a sustainable and environmentally friendly option (4). However, the incorporation of compounds into the food packaging system at nanoscale (particle size between 1 and $100 \mathrm{~nm}$ ) has raised concerns on their migration and release into food matrices and the health effects lying with the consumption of such foodstuffs. Hence, it becomes paramount to study the migration behavior into food matrices and associated toxicity after entering the human body as well as the biodegradability/toxicity and its role in the environment.

Several concerns on the use of nanoparticles (NPs), their release kinetics, absorption behavior in the body, degradation kinetics and their long-term effects are uncertain and unexplored, therefore, in-depth research is required on these aspects to understand the broader figure of the story. Hence, we strongly recommend exploring these aspects to reveal and disseminate the underlying safety concerns associated with the use of nano-encapsulated particles and to avoid any unfortunate and unprecedented outcomes in the future.

\section{ABSORPTION BEHAVIOR OF NANOPARTICLES IN THE BODY}

The particles within nanometer range may behave differently within the human body with different biological fate i.e., the levels of absorption, distribution, metabolism, excretion and potential. The biological fate of NPs is dependent on their physicochemical properties (e.g., composition, dimensions, interfacial properties structure and physical state) as well as the changes they undergo while passing the gastrointestinal tract (GIT) (5). For example, the biological fate of lipid NP varies depending on whether it is directly absorbed or normally digested by the human body $(6,7)$. The smaller indigestible NPs accumulate in organs at a faster rate compared to a larger size. Besides this, metallic $(\mathrm{Ag}$ and $\mathrm{Au})$ and inorganic $\left(\mathrm{TiO}_{2}\right.$ and $\left.\mathrm{SiO}_{2}\right)$ non-digestible nanoparticles are reported to cross the layer of epithelial cells through various routes such as paracellular, transcellular, or persorption (8). Similarly, mineralo-organic NPs formed from calcium, carbonate and phosphate can lead to ectopic calcification and kidney stones. Further the mineral particles may be involved in the immune tolerance against the gut microbiota and food antigens (9). The NP may be either digested, accumulated or transferred into the systemic circulation via the blood or lymph systems after being absorbed into an epithelium cell (10). NPs may translocate through the human body followed by metabolization, excretion, or accumulation within certain tissues after exiting 

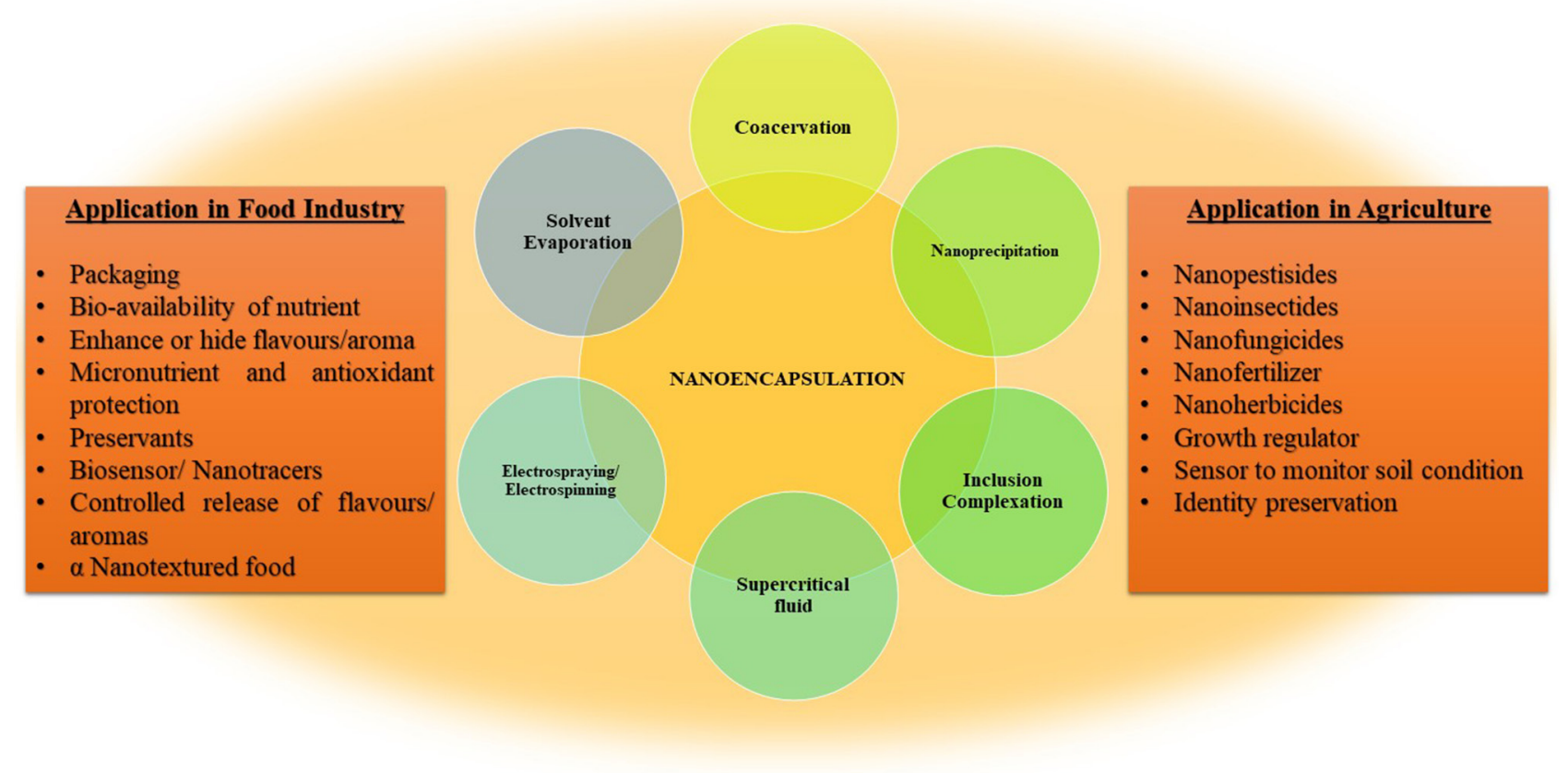

Coacervation

Graphical Abstract | Applications of nanoencapsulation for agri-food industry.

epithelial cells (6). However, an in-depth investigation is desired to reveal the fate of direct adsorption of both indigestible and digestible lipid NPs in humans.

Fu et al. (11) observed the toxic effects of Ag NPs after being absorbed through the intestine to the liver of the mice when administered orally. The Ag NPs were also reported in spleen and liver when administered intravenously. However, with a lower absorption rate and the NPs were finally excreted through urine and feces. Choi et al. (12) demonstrated that non-cationic surface charged NPs $(<34 \mathrm{~nm})$ could efficiently translocate from the lungs to mediastinal lymph nodes. NPs $(<6 \mathrm{~nm})$ were rather translocated rapidly from lungs via lymph nodes to the bloodstream and finally cleared by the kidneys. Further, Gerloff et al. (13) reported the cytotoxic with DNA damaging effects of $\mathrm{TiO}_{2}, \mathrm{SiO}_{2}, \mathrm{ZnO}$ and $\mathrm{MgO}$ NPs along with carbon black on human intestinal Caco-2 cells. Alterations in the microbiome in GIT leads to various gut disorders like inflammatory bowel diseases and metabolic syndrome (14). It is speculated that $\mathrm{TiO}_{2}$ and Ag NPs may alter the gut microbiota (15). This is attributable to the antimicrobial property of NPs and the production of reactive oxygen species (ROS) $(15,16)$. However, further indepth research is required to reveal the absorption behavior and biological fate of various NPs.

\section{RELEASE KINETICS OF NANOPARTICLES}

The release of bioactive compounds is referred to their translocation from one site to another over a time period. Several factors influence the release of NPs, namely (i) thermodynamic factors; (ii) kinetic factors; (iii) chemical structure, particle size and weight of nano-encapsulates; (iv) physicochemical properties like volatility and hydrophobicity; (v) concentration; and (vi) oral processing behavior (17). Release of the bioactive components at the target site known as "Targetability" is another important aspect of release kinetics. This can be achieved through the utilization of liposomes, nanoliposomes or any other nanocarrier systems. The target mechanism can be either active or passive. For example, incorporating antibodies in the lipid carriers is a form of active mechanism while targeting through the particle size of the vesicles is a passive form $(18,19)$.

Several in vivo studies using various NPs demonstrate hazard identification, however, caution should be taken while extrapolating their mechanistic results for hazard characterization and subsequent risk on human health (20). Different NPs have been reported to trigger the release of ROS and subsequently leading to oxidative stress and inflammation via their interaction with the reticuloendothelial system (20). NPs do not bind to the cell membrane but have direct access to the intracellular proteins, organelles and DNA, thereby leading to potential toxicity (21). Having said that, the plausible interactions of NPs with cell components are not fully understood and need further in-depth research. Few studies suggest that NPs may pass the blood-brain barrier but still not clear whether it is a generic effect or shown only by specific subgroup (22). Further, the transfer of NPs across the placenta or via breast milk has the potential for embryotoxicity (23). The data on distribution behavior of NPs in the reproductive cells are insufficient to draw any conclusion. Therefore, investigation should be focused on repro-toxicity of NPs and their passage through the placenta (6). 
In addition, after the release of NPs into the environment, surface water forms on the NP's surface creating the entry points and dispersion into soil and soil biota. At this stage, NPs undergo various transformations such as physical, chemical and biological transformations (24). NPs can be bio/geo-transformed in the soil leading to their toxicity, generation of oxidative stress, and absorption by plants that ultimately pose alarming concerns for human health via entering into the food chain (25). NPs get absorbed through roots and then translocate and accumulate to aerial parts via biotransformation and bioaccumulation (26). These scenarios highlight the need for in-depth kinetic studies of NPs and their potential health and environmental concerns.

\section{TOXICITY OF NANOPARTICLES}

Among the various compounds, food-grade $\mathrm{TiO}_{2}$ is widely used for food applications and hence the safety aspects of its NPs should be evaluated (27). Studies suggest $\mathrm{TiO}_{2} \mathrm{NPs}$ to be more toxic compared to larger particles of $\mathrm{TiO}_{2}$ (28). Oral ingestion of $\mathrm{TiO}_{2}(>100 \mathrm{~nm})$ has a lower toxicity than $\mathrm{TiO}_{2}(<100 \mathrm{~nm})$ (29). A study revealed an elevated level of elemental Ti in human blood for $6 \mathrm{~h}$ after intake of food-grade $\mathrm{TiO}_{2}$ (30) suggesting easy absorption of NPs in the GIT (31). Besides this, $\mathrm{TiO}_{2} \mathrm{NPs}$ may lead to reproductive issues upon acute oral exposure. For example, Philbrook et al. (32) observed fatality in pregnant mice treated with 100 and $1,000 \mathrm{mgkg}^{-1} \mathrm{TiO}_{2}$ NPs. In addition, the effects on cardiac and inflammatory responses (33); blood and bone marrow system (34) were noticed in mice exposed to $\mathrm{TiO}_{2}$ NPs.
Another aspect of toxicity lies with how NPs interact with various food components. NPs can interact with food components (e.g., phospholipids, sugars, nucleic acids) and influence the absorption and release kinetics (35). Proteins along with other biomolecules bind and trap NPs which affects their digestion process. Similarly, carbohydrates, fatty acids and proteins play a significant role in the uptake of Ag NPs into Caco2 cells where food components resulted in enhanced uptake of NPs by $60 \%$ (36). In addition, water activity of food impacts the release kinetics of NPs (37). $\mathrm{pH}$ and composition of the food also affect the stability, dissolution, and toxicity of NPs (38). Solubility is another crucial factor for the toxicity of $\mathrm{NPs}$. TiO 2 and $\mathrm{SiO}_{2}$ NPs are insoluble while Ag and ZnO NPs are partially/completely soluble in GIT fluids (37). Therefore, uptake and toxicity of soluble NPs (e.g., ZnO NPs) are enhanced (39).

Further, the cytotoxic effects of Ag NPs via altered membrane permeability and integrity has been observed in mammalian cells (40). NPs entering the mammalian cells via endocytosis are translocated to lysosomes, while NPs passing the plasma membrane via diffusion enter the cytoplasm and are less toxic compared to earlier (41). NPs attach to the membrane proteins, damage mitochondria and DNA, produce ROS, alter enzyme activity, integrity and functions of cells (40). The toxicity is a result of Ag NPs interaction with proteins and creation of protein corona with altered functions (42). Even the changes and mutation in DNA may occur (43). However, toxicity varies with the type of NPs and therefore, proper hazard analysis of all types of NPs for food applications are essential (44).

The wide applications of nano-fertilizers and nano-pesticides into the cultivated soils for agri-food production have concerns for their long-term effects which needs to be evaluated (45). For

TABLE 1 | Nanoencapsulation of bioactive compounds for agri-food applications.

\begin{tabular}{|c|c|c|c|c|}
\hline Bioactive compound & $\begin{array}{l}\text { Nanoencapsulation } \\
\text { technique }\end{array}$ & Wall material & Application & References \\
\hline Vitamin $B_{2}$, Vitamin $C$ & Ionic gelation & Alginate/chitosan & $\begin{array}{l}\text { Controlled release of vitamins for usage in food } \\
\text { industry }\end{array}$ & $(53,54)$ \\
\hline $\begin{array}{l}\text { Satureja hortensis L. } \\
\text { Essential Oil (EO) }\end{array}$ & Ionic gelation & $\begin{array}{l}\text { Sodium } \\
\text { trypolyphosphate-Chitosan }\end{array}$ & $\begin{array}{l}\text { As antimicrobial and antioxidant agents with } \\
\text { enhanced stability against adverse } \\
\text { environmental conditions }\end{array}$ & (55) \\
\hline Curcumin & Coacervation & Chitosan & $\begin{array}{l}\text { Enhanced antioxidant activity with novel } \\
\text { delivery system }\end{array}$ & $(56)$ \\
\hline Glucose oxidase & Electrospinning & $\begin{array}{l}\text { Polyvinyl-alcohol/chitosan/tea- } \\
\text { extract }\end{array}$ & $\begin{array}{l}\text { Novel food packaging system for food } \\
\text { preservation }\end{array}$ & $(57)$ \\
\hline Eugenol & Emulsion-ionic gelation & Trypolyphosphate-Chitosan & $\begin{array}{l}\text { For improved thermal stability and antioxidant } \\
\text { activity }\end{array}$ & $(58)$ \\
\hline Oil: Medium chain triglyceride & $\begin{array}{l}\text { High-pressure } \\
\text { homogenized emulsions } \\
\text { and layer-by-layer shell } \\
\text { assembly }\end{array}$ & $\begin{array}{l}\text { Modified starch- chitosan-lambda } \\
\text { carrageenan }\end{array}$ & $\begin{array}{l}\text { Development of nanocapsules for food } \\
\text { industries }\end{array}$ & (59) \\
\hline Lysozyme & $\begin{array}{l}\text { Electrospinning- layer by } \\
\text { layer assembly }\end{array}$ & Chitosan & $\begin{array}{l}\text { Preservation of pork against Escherichia coli } \\
\text { and Staphylococcus aureus }\end{array}$ & $(60)$ \\
\hline Lippia sidoides EO & Spray drying & Angico gum/chitosan & For enhanced release property & $(61)$ \\
\hline$\alpha$-tocopherol & Freeze drying & Zein-chitosan & $\begin{array}{l}\text { Enhanced stability and protection against } \\
\text { environmental conditions }\end{array}$ & $(62)$ \\
\hline Lime EO & Nanoprecipitation & Chitosan & $\begin{array}{l}\text { Antibacterial properties against food-borne } \\
\text { pathogens }\end{array}$ & (63) \\
\hline
\end{tabular}


example, it is estimated that $95 \%$ of $\mathrm{Cu}$ used will eventually end accumulating with a concentration of $500 \mathrm{\mu gkg}^{-1}$ (46) and $\mathrm{ZnO}$ up to $16 \mathrm{\mu gkg}^{-1}$ (47) in the soil and aquatic sediments. Studies have shown NPs causing damage to the lung in rats by the consumption of $\mathrm{TiO}_{2} \mathrm{NPs}(20 \mathrm{~nm})$ and Fe NPs (48). Further, $\mathrm{TiO}_{2} \mathrm{NPs}$ potentially damage the brain in dogs and fish (49). Both $\mathrm{Ag}$ and $\mathrm{TiO}_{2}$ NPs have demonstrated cytotoxic and genotoxic effects due to ROS generation leading to cell proliferation and DNA damage in mice and human cells (50). Therefore, NPs could be dangerous for both human beings and the environment. Hence the application of nanoencapsulation and associated NPs for agri-food application should be tackled with great care and responsibility. The unauthorized and haphazard use of NPs can contaminate both soil and plant systems and ultimately intoxicate the agricultural ecosystem (51).

\section{DISCUSSION}

Nanoparticles are widely used in agriculture and food sector for enhancing the productivity and quality of foods (52). Despite the various positive applications of nano-encapsulated bioactive compounds widely reported by several studies for agrifood applications (Table 1), the associated potential risks for human health should not be underestimated. The mechanisms of release kinetics of nanoparticles from various formulations and production processes need to be characterized and fully elucidated. In addition, the knowledge gap concerning the biological fate, distribution and accumulation of NPs in humans raises concerns for their use and potential toxic effects (6).

The applications of NPs for food packaging can cause toxic effects upon migration of the NPs from packaging system to the foodstuffs (64). Since nanotoxicology and nanoecotoxicology are

\section{REFERENCES}

1. Jafari SM, Arpagaus C, Cerqueira MA, Samborska K. Nano spray drying of food ingredients; materials, processing and applications. Trends Food Sci Technol. (2021) 109:632-46. doi: 10.1016/j.tifs.2021.01.061

2. Katouzian I, Jafari SM. Nano-encapsulation as a promising approach for targeted delivery and controlled release of vitamins. Trends Food Sci Technol. (2016) 53:34-48. doi: 10.1016/j.tifs.2016.05.002

3. Shishir MRI, Xie L, Sun C, Zheng X, Chen W. Advances in micro and nano-encapsulation of bioactive compounds using biopolymer and lipid-based transporters. Trends Food Sci Technol. (2018) 78:34-60. doi: 10.1016/j.tifs.2018.05.018

4. Tang XZ, Kumar P, Alavi S, Sandeep KP. Recent advances in biopolymers and biopolymer-based nanocomposites for food packaging materials. Crit Rev Food Sci Nutr. (2012) 52:426-42. doi: 10.1080/10408398.2010.5 00508

5. Wang T, Luo Y. Biological fate of ingested lipid-based nanoparticles: current understanding and future directions. Nanoscale. (2019) 11:1104863. doi: 10.1039/C9NR03025E

6. Bouwmeester H, Dekkers S, Noordam MY, Hagens WI, Bulder AS, De Heer C, et al. Review of health safety aspects of nanotechnologies in food production. Regul Toxicol Pharmacol. (2009) 53:52-62. doi: 10.1016/j.yrtph.2008.10.008

7. Hagens WI, Oomen AG, de Jong WH, Cassee FR, Sips AJAM. What do we (need to) know about the kinetic properties of nanoparticles in the body? Regul Toxicol Pharmacol. (2007) 49:217-29. doi: 10.1016/j.yrtph.2007.07.006 novel scientific fields, therefore risk assessments are paramount (65). In addition, the proper rules and regulations need to be set up to check the haphazard and extensive use of NPs without investigating the possible long-term effects on human and animal health. The lack of information on risk assessment and proper regulation highlights the need for further in-depth research (66).

Therefore, with these unanswered questions and valid reasons for health and environmental concerns associated with the use of NPs for agri-food application, we strongly advocate for in-depth and unbiased additional research in the field to ensure safe and sustainable agri-food products. This will further guarantee the safety and security of food and nutrition for human and animal health besides a sustainable environment.

\section{CONCLUSION}

As concluding remarks, there is an urgency to increase and spread the knowledge and perception on NPs, their beneficial applications as well as associated risk for agri-food applications and how to tackle them to guarantee the safe, healthy and sustainable agri-food and environment for future generations.

\section{AUTHOR CONTRIBUTIONS}

DKM wrote the original draft. AKM help in editing during article. PK conceptualized the manuscript and did the final editing of all sections.

\section{ACKNOWLEDGMENTS}

The authors are grateful to the higher authority and the respective departments, institutions, and universities.
8. Powell JJ, Faria N, Thomas-McKay E, Pele LC. Origin and fate of dietary nanoparticles and microparticles in the gastrointestinal tract. J Autoimmun. (2010) 34:J226-33. doi: 10.1016/j.jaut.2009.11.006

9. Martel J, Wu C-Y, Peng H-H, Young JD. Mineralo-organic nanoparticles in health and disease: an overview of recent findings. Nanomedicine. (2018) 13:1787-93. doi: 10.2217/nnm-2018-0108

10. Fröhlich E, Roblegg E. Models for oral uptake of nanoparticles in consumer products. Toxicology. (2012) 291:10-7. doi: 10.1016/j.tox.2011.11.004

11. Fu C, Liu T, Li L, Liu H, Chen D, Tang F. The absorption, distribution, excretion and toxicity of mesoporous silica nanoparticles in mice following different exposure routes. Biomaterials. (2013) 34:2565-75. doi: 10.1016/j.biomaterials.2012.12.043

12. Choi HS, Ashitate $\mathrm{Y}$, Lee JH, Kim SH, Matsui A, Insin N, et al. Rapid translocation of nanoparticles from the lung airspaces to the body. Nat Biotechnol. (2010) 28:1300-3. doi: 10.1038/nbt.1696

13. Gerloff K, Albrecht C, Boots AW, Förster I, Schins RPF. Cytotoxicity and oxidative DNA damage by nanoparticles in human intestinal Caco-2 cells. Nanotoxicology. (2009) 3:355-64. doi: 10.3109/17435390903276933

14. Velázquez KT, Enos RT, Bader JE, Sougiannis AT, Carson MS, Chatzistamou I, et al. Prolonged high-fat-diet feeding promotes non-alcoholic fatty liver disease and alters gut microbiota in mice. World J Hepatol. (2019) 11:619. doi: 10.4254/wjh.v11.i8.619

15. Chen Z, Zhou D, Han S, Zhou S, Jia G. Hepatotoxicity and the role of the gutliver axis in rats after oral administration of titanium dioxide nanoparticles. Part Fibre Toxicol. (2019) 16:48. doi: 10.1186/s12989-019-0332-2 
16. Chen F, Yang X, Xu F, Wu Q, Zhang Y. Correlation of photocatalytic bactericidal effect and organic matter degradation of $\mathrm{TiO}_{2}$ part I: observation of phenomena. Environ Sci Technol. (2009) 43:1180-4. doi: 10.1021/es802499t

17. Zuidam NJ, Heinrich E. Encapsulation of Aroma. Encapsulation Technologies for Active Food Ingredients and Food Processing. Berlin: Springer (2010). p. 127-60.

18. Panigrahi SS, Syed I, Sivabalan S, Sarkar P. Nanoencapsulation strategies for lipid-soluble vitamins. Chem Papers. (2019) 73:1-16. doi: 10.1007/s11696-018-0559-7

19. Rafiee Z, Jafari SM. Application of lipid nanocarriers for the food industry. In: Mérillon JM, Ramawat K, editors. Bioactive Molecules in Food. Reference Series in Phytochemistry. Cham: Springer (2019).

20. Oberdörster G, Stone V, Donaldson K. Toxicology of nanoparticles: a historical perspective. Nanotoxicology. (2007) 1:2-25. doi: 10.1080/17435390701314761

21. Kabanov AV. Polymer genomics: an insight into pharmacology and toxicology of nanomedicines. Adv Drug Deliv Rev. (2006) 58:1597621. doi: 10.1016/j.addr.2006.09.019

22. Borm P, Klaessig FC, Landry TD, Moudgil B, Pauluhn Jr, Thomas K, et al. Research strategies for safety evaluation of nanomaterials, part V: role of dissolution in biological fate and effects of nanoscale particles. Toxicol Sci. (2006) 90:23-32. doi: 10.1093/toxsci/kfj084

23. Fujimoto A, Tsukue N, Watanabe M, Sugawara I, Yanagisawa R, Takano H, et al. Diesel exhaust affects immunological action in the placentas of mice. Environ Toxicol. (2005) 20:431-40. doi: 10.1002/tox.20129

24. Lowry GV, Gregory KB, Apte SC, Lead JR. Transformations of Nanomaterials in the Environment. Washington, DC: ACS Publications (2012).

25. Rajput VD, Minkina T, Sushkova S, Tsitsuashvili V, Mandzhieva S, Gorovtsov A, et al. Effect of nanoparticles on crops and soil microbial communities. $J$ Soils Sediments. (2018) 18:2179-87. doi: 10.1007/s11368-017-1793-2

26. Peng C, Duan D, Xu C, Chen Y, Sun L, Zhang H, et al. Translocation and biotransformation of $\mathrm{CuO}$ nanoparticles in rice (Oryza sativa L.) plants. Environ Pollut. (2015) 197:99-107. doi: 10.1016/j.envpol.2014.12.008

27. Chen Z, Han S, Zhou S, Feng H, Liu Y, Jia G. Review of health safety aspects of titanium dioxide nanoparticles in food application. NanoImpact. (2020) 18:100224. doi: 10.1016/j.impact.2020.100224

28. Kang JL, Moon C, Lee HS, Lee HW, Park E-M, Kim HS, et al. Comparison of the biological activity between ultrafine and fine titanium dioxide particles in RAW 264.7 cells associated with oxidative stress. J Toxicol Environ Health Part A. (2008) 71:478-85. doi: 10.1080/15287390801906675

29. Warheit DB, Donner EM. Risk assessment strategies for nanoscale and fine-sized titanium dioxide particles: recognizing hazard and exposure issues. Food Chem Toxicol. (2015) 85:138-47. doi: 10.1016/j.fct.2015. 07.001

30. Pele LC, Thoree V, Bruggraber SFA, Koller D, Thompson RPH, Lomer MC, et al. Pharmaceutical/food grade titanium dioxide particles are absorbed into the bloodstream of human volunteers. Part Fibre Toxicol. (2015) 12:16. doi: 10.1186/s12989-015-0101-9

31. Date AA, Hanes J, Ensign LM. Nanoparticles for oral delivery: design, evaluation and state-of-the-art. J Control Release. (2016) 240:504-26. doi: 10.1016/j.jconrel.2016.06.016

32. Philbrook NA, Winn LM, Afrooz AN, Saleh NB, Walker VK. The effect of $\mathrm{TiO}_{2}$ and Ag nanoparticles on reproduction and development of Drosophila melanogaster and CD-1 mice. Toxicol Appl Pharmacol. (2011) 257:42936. doi: 10.1016/j.taap.2011.09.027

33. Chen Z, Zhou D, Wang Y, Zhao L, Hu G, Liu J, et al. Combined effect of titanium dioxide nanoparticles and glucose on the cardiovascular system in young rats after oral administration. J Appl Toxicol. (2019) 39:590602. doi: $10.1002 /$ jat. 3750

34. Trouiller B, Reliene R, Westbrook A, Solaimani P, Schiestl RH. Titanium dioxide nanoparticles induce DNA damage and genetic instability in vivo in mice. Cancer Res. (2009) 69:8784-9. doi: 10.1158/0008-5472.CAN-09-2496

35. Cao Y, Li J, Liu F, Li X, Jiang Q, Cheng S, et al. Consideration of interaction between nanoparticles and food components for the safety assessment of nanoparticles following oral exposure: a review. Environ Toxicol Pharmacol. (2016) 46:206-10. doi: 10.1016/j.etap.2016.07.023

36. Lichtenstein D, Ebmeyer J, Knappe P, Juling S, Böhmert L, Selve S, et al. Impact of food components during in vitro digestion of silver nanoparticles on cellular uptake and cytotoxicity in intestinal cells. Biol Chem. (2015) 396:1255-64. doi: 10.1515/hsz-2015-0145

37. McClements DJ, Xiao $\mathrm{H}$, Demokritou P. Physicochemical and colloidal aspects of food matrix effects on gastrointestinal fate of ingested inorganic nanoparticles. Adv Colloid Interface Sci. (2017) 246:165-80. doi: 10.1016/j.cis.2017.05.010

38. Roy I, Ohulchanskyy TY, Pudavar HE, Bergey EJ, Oseroff AR, Morgan J, et al. Ceramic-based nanoparticles entrapping water-insoluble photosensitizing anticancer drugs: a novel drug- carrier system for photodynamic therapy. $J$ Am Chem Soc. (2003) 125:7860-5. doi: 10.1021/ja0343095

39. Wang Y, Yuan L, Yao C, Ding L, Li C, Fang J, et al. A combined toxicity study of zinc oxide nanoparticles and vitamin $\mathrm{C}$ in food additives. Nanoscale. (2014) 6:15333-42. doi: 10.1039/C4NR05480F

40. McShan D, Ray PC, Yu H. Molecular toxicity mechanism of nanosilver. J Food Drug Anal. (2014) 22:116-27. doi: 10.1016/j.jfda.2014.01.010

41. Fröhlich EE, Fröhlich E. Cytotoxicity of nanoparticles contained in food on intestinal cells and the gut microbiota. Int J Mol Sci. (2016) 17:509. doi: 10.3390/ijms17040509

42. Saptarshi SR, Duschl A, Lopata AL. Interaction of nanoparticles with proteins: relation to bio-reactivity of the nanoparticle. J Nanobiotechnol. (2013) 11:112. doi: 10.1186/1477-3155-11-26

43. Huk A, Izak-Nau E, El Yamani N, Uggerud H, Vadset M, Zasonska B, et al. Impact of nanosilver on various DNA lesions and HPRT gene mutationseffects of charge and surface coating. Part Fibre Toxicol. (2015) 12:120. doi: 10.1186/s12989-015-0100-x

44. Karimi M, Sadeghi R, Kokini J. Human exposure to nanoparticles through trophic transfer and the biosafety concerns that nanoparticle-contaminated foods pose to consumers. Trends Food Sci Technol. (2018) 75:12945. doi: 10.1016/j.tifs.2018.03.012

45. Sekhon BS. Nanotechnology in agri-food production: an overview. Nanotechnol Sci Appl. (2014) 7:31. doi: 10.2147/NSA.S39406

46. Keller AA, Adeleye AS, Conway JR, Garner KL, Zhao L, Cherr $\mathrm{GN}$, et al. Comparative environmental fate and toxicity of copper nanomaterials. NanoImpact. (2017) 7:28-40. doi: 10.1016/j.impact.2017. 05.003

47. Feng X, Yupeng Y, Biao W, Wei L, Deb PJ, Lirong Z, et al. Enhanced dissolution and transformation of $\mathrm{ZnO}$ nanoparticles: the role of inositol hexakisphosphate. Environ Sci Technol. (2016) 50:5651-60. doi: 10.1021/acs.est.6b00268

48. Gonzalez L, Lison D, Kirsch-Volders M. Genotoxicity of engineered nanomaterials: a critical review. Nanotoxicology. (2008) 2:252-73. doi: 10.1080/17435390802464986

49. Shaw BJ, Handy RD. Physiological effects of nanoparticles on fish: a comparison of nanometals versus metal ions. Environ Int. (2011) 37:108397. doi: 10.1016/j.envint.2011.03.009

50. Mohamed HRH, Hussien NA. Genotoxicity studies of titanium dioxide nanoparticles $\left(\mathrm{TiO}_{2} \mathrm{NPs}\right)$ in the brain of mice. Scientifica. (2016) 2016:6710840. doi: 10.1155/2016/6710840

51. Rajput V, Minkina T, Mazarji M, Shende S, Sushkova S, Mandzhieva $\mathrm{S}$, et al. Accumulation of nanoparticles in the soil-plant systems and their effects on human health. Ann Agric Sci. (2020) 65:137-43. doi: 10.1016/j.aoas.2020.08.001

52. He $\mathrm{X}$, Deng $\mathrm{H}$, Hwang H-M. The current application of nanotechnology in food and agriculture. J Food Drug Anal. (2019) 27:1-21. doi: 10.1016/j.jfda.2018.12.002

53. Azevedo MA, Bourbon AI, Vicente AA, Cerqueira MA. Alginate/chitosan nanoparticles for encapsulation and controlled release of vitamin B2. Int J Biol Macromol. (2014) 71:141-6. doi: 10.1016/j.ijbiomac.2014.05.036

54. Jiménez-Fernández E, Ruyra A, Roher N, Zuasti E, Infante C, Fernández-Díaz C. Nanoparticles as a novel delivery system for vitamin C administration in aquaculture. Aquaculture. (2014) 432:426-33. doi: 10.1016/j.aquaculture.2014.03.006

55. Feyzioglu GC, Tornuk F. Development of chitosan nanoparticles loaded with summer savory (Satureja hortensis L.) essential oil for antimicrobial and antioxidant delivery applications. LWT- Food Sci Technol. (2016) 70:10410. doi: 10.1016/j.lwt.2016.02.037

56. Tan C, Feng B, Zhang X, Xia W, Xia S. Biopolymer-coated liposomes by electrostatic adsorption of chitosan (chitosomes) as 
novel delivery systems for carotenoids. Food Hydrocoll. (2016) 52:774-84. doi: 10.1016/j.foodhyd.2015.08.016

57. Ge L, Zhao Y-s, Mo T, Li J-r, Li P. Immobilization of glucose oxidase in electrospun nanofibrous membranes for food preservation. Food Control. (2012) 26:188-93. doi: 10.1016/j.foodcont.2012.01.022

58. Woranuch S, Yoksan R. Eugenol-loaded chitosan nanoparticles: I. Thermal stability improvement of eugenol through encapsulation. Carbohydr Polym. (2013) 96:578-85. doi: 10.1016/j.carbpol.2012.08.117

59. Preetz C, Rübe A, Reiche I, Hause G, Mäder K. Preparation and characterization of biocompatible oil-loaded polyelectrolyte nanocapsules. Nanomedicine. (2008) 4:106-14. doi: 10.1016/j.nano.2008.03.003

60. Huang W, Xu H, Xue Y, Huang R, Deng H, Pan S. Layer-by-layer immobilization of lysozyme-chitosan-organic rectorite composites on electrospun nanofibrous mats for pork preservation. Food Res Int. (2012) 48:784-91. doi: 10.1016/j.foodres.2012.06.026

61. Paula HCB, Sombra FM, Abreu FOM, Paul R. Lippia sidoides essential oil encapsulation by angico gum/chitosan nanoparticles. J Braz Chem Soc. (2010) 21:2359-66. doi: 10.1590/S0103-50532010001200025

62. Luo Y, Zhang B, Whent M, Yu LL, Wang Q. Preparation and characterization of zein/chitosan complex for encapsulation of $\alpha$-tocopherol, and its in vitro controlled release study. Colloids Surf B: Biointerfaces. (2011) 85:14552. doi: 10.1016/j.colsurfb.2011.02.020

63. Sotelo-Boyás ME, Correa-Pacheco ZN, Bautista-Baños S, Corona-Rangel ML. Physicochemical characterization of chitosan nanoparticles and nanocapsules incorporated with lime essential oil and their antibacterial activity against food-borne pathogens. LWT- Food Sci Technol. (2017) 77:1520. doi: 10.1016/j.lwt.2016.11.022

64. Huang J-Y, Li X, Zhou W. Safety assessment of nanocomposite for food packaging application. Trends Food Sci Technol. (2015) 45:18799. doi: 10.1016/j.tifs.2015.07.002

65. Xavier M, Parente I, Rodrigues P, Cerqueira MA, Pastrana L, Gonçalves C. Safety and fate of nanomaterials in food: the role of in vitro tests. Trends Food Sci Technol. (2021) 109:593-607. doi: 10.1016/j.tifs.2021.01.050

66. Souza VGL, Fernando AL. Nanoparticles in food packaging: biodegradability and potential migration to food-A review. Food Packag Shelf Life. (2016) 8:63-70. doi: 10.1016/j.fpsl.2016.04.001

Conflict of Interest: The authors declare that the research was conducted in the absence of any commercial or financial relationships that could be construed as a potential conflict of interest.

Copyright (C) 2021 Mahato, Mishra and Kumar. This is an open-access article distributed under the terms of the Creative Commons Attribution License (CC BY). The use, distribution or reproduction in other forums is permitted, provided the original author(s) and the copyright owner(s) are credited and that the original publication in this journal is cited, in accordance with accepted academic practice. No use, distribution or reproduction is permitted which does not comply with these terms. 